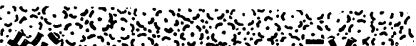

री

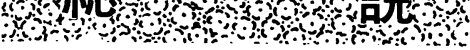

\title{
粒状農産物のマイコトキシン検査におけるサンプリング法に 関する統計学的考察
}

山本 勝 彦*1

\section{Statistical Consideration of Sampling Plan for Mycotoxin Test of Granular Agricultural Products}

\section{Katsuhiko Yамамото}

(Food Department, Nagoya City Public Health Research Institute: 1-11, Hagiyama-cho, Mizuho-ku, Nagoya, Japan)

\section{1. はじめに}

世界の食用農産物のおよそ $25 \%$ はマイコトキシンに よって何らかの影響を被っていると FAO が推定してい るように, 主要な穀類, 豆類, 種実類などは, ことごと くカビ污染の前に晒されている. アフラトキシン（以下， $\mathrm{AF}$ と略す）の驚異的な発がん性の強さが明らかにされ て以来, 食品や飼料のマイコトキシン污染に関する品質 管理及び人畜などのマイコトキシンによる暴露状況の把 握などは最も重要な課題の一つとして認識された。 そし て，これらのマイコトキシンに対する許容基準の設定, それに前後して幾多の分析法の開発及び改善がなされて きた. 今日, マイコトキシンの中でも特に AF に対して は，世界で 50 に上る諸国が，食品及び飼料に何らかの 規制を設けている.

しかし，一方では何十トンといった多量のロット（母 集団）から構成される農産物のマイコトキシン污染レベ ルを正確に把握するには，非常に難しい問題が残されて いる.

粒状の農産物のマイコトキシンは, 同一のロット内で もごく少数の粒に非常に不均一に分布する．この不均一 性は, サンプルの測定值からロットの污染濃度を推定す る際に，大きな変動を来す原因となることが知られてい る. したがって, このような農産物の生産者にとっては, 適正なサンプリング法を定めることが基本的な課題とな った。本格的には，世界の穀倉地帯といわれるアメリカ 合衆国において取り組まれた。 1971 年，ちょうど我が

\footnotetext{
*1 名古屋市衛生研究所：名古屋市瑞穂区萩山町 1-11
}

国が初めて輸入の落花生とその加工品の AF 規制を設け た時期には，既に，多量のロットを検査する際のサンプ リング法を統計学的に評価する研究が進められていた.

Whitaker らは，剥き身落花生 ${ }^{1) ~ 3)}$ 及び脱穀したトウ モロコシ4)の粒ごとの AF 濃度の出現率が，確率分布法 則の一つである負の二項分布法則に従うことを見いだし た.この負の二項分布法則から誘導した検査特性曲線 (Operating Characteristic Curve; OC-曲線）を用いて, マイコトキシン検査の際のサンプリング法を評価する方 法を考案した。著者は，彼らの報告と，それに呼応する 諸国の研究者の報告に接するうちに，各国の検査法を一 つのテーブルの上で，同じ物差しで比較することは，統 計学上の考え方を一層理解しやすくなることに気づい た.

さらに，著者は，粒状の穀類，豆類及び種実類のマイ コトキシン検查の際に必要なサンプルサイズを二項分布 法則を用いて検討してきた．特にサンプル中の污染粒の 混在率（以下，污染粒率と呼ぶ）とマイコトキシンを検 出できる確率（以下，検出確率と呼ぶ）を想定して，必 要なサンプル量を試算した。

ここでは，主としてマイコトキシンの各種農産物での 粒污染状況を述べ，これら二つの確率統計理論に基づい て，マイコトキシン検査の際のサンプリングの評価とい う観点から解説したい.

2. 豆類, 穀類及び種実類のマイコトキシンの粒污染 状況

剝き身落花生における AF の粒污染：表 1 に剝き身落 花生の粒ごとの AF 污染事例を示した.ロット 1 は 
表 1. 不良品として選別された剝き身落花生粒中のアフラトキシン $\mathrm{B}_{1}$ 量の分布

\begin{tabular}{|c|c|c|c|}
\hline & ロット $1^{* 1}$ & ロット $2^{* 2}$ & ロット $3^{* 3}$ \\
\hline 全粒数 (\%) & $20(100 \%)$ & $330(100 \%)$ & $100(100 \%)$ \\
\hline AF 不検出粒数 (\%) & $8(40.0 \%)$ & $255(77.3 \%)$ & $78(78.0 \%)$ \\
\hline \multicolumn{4}{|l|}{ 【AFB ${ }_{1}$ 量 $X$ の検出範囲】 } \\
\hline \multicolumn{4}{|l|}{ A. $X \leqq 0.5 \mu \mathrm{g} /$ 粒 } \\
\hline 検出粒数 (\%) & $1(5.0 \%)$ & $5(1.5 \%)$ & $14(14.0 \%)$ \\
\hline 平均土標準偏差 $\mu \mathrm{g} /$ 粒 & 0.174 & $0.273 \pm 0.103$ & $0.069 \pm 0.052$ \\
\hline 範囲 $\mu \mathrm{g} /$ 粒 & & $0.117 \sim 0.397$ & $0.008 \sim 0.164$ \\
\hline \multicolumn{4}{|l|}{ B. $\quad 0.5 \mu \mathrm{g}<X \leqq 10 \mu \mathrm{g} /$ 粒 } \\
\hline 検出粒数 (\%) & $5(25.0 \%)$ & $25(7.6 \%)$ & $4(4.0 \%)$ \\
\hline 平均土標準偏差 $\mu \mathrm{g} /$ 粒 & $1.18 \pm 0.42$ & $4.46 \pm 2.34$ & $2.01 \pm 0.73$ \\
\hline 範囲 $\mu \mathrm{g} /$ 粒 & $0.50 \sim 1.5$ & $0.64 \sim 7.89$ & $1.20 \sim 3.00$ \\
\hline \multicolumn{4}{|l|}{ C. $10 \mu \mathrm{g}<X \mu \mathrm{g} /$ 粒 } \\
\hline 検出粒数 (\%) & $6(30.0 \%)$ & $45(13.6 \%)$ & $4(4.0 \%)$ \\
\hline 平均土標準偏差 $\mu \mathrm{g} /$ 粒 & $161 \pm 150$ & $55.8 \pm 63.9$ & $39.7 \pm 33.9$ \\
\hline 範囲 $\mu \mathrm{g} /$ 粒 & $18.9 \sim 418$ & $11.2 \sim 341$ & $13.4 \sim 97.0$ \\
\hline \multirow{2}{*}{ 比率: $\frac{\mathrm{C}}{\mathrm{B}+\mathrm{C}}$} & 1 & 1 & 1 \\
\hline & 1.8 & 1.6 & 2 \\
\hline
\end{tabular}

${ }^{* 1}$ : 文献 5$) ; *^{2}$ ：文献 6$) ; *^{*}$ : 文献 8) より引用

Cucullu $^{5)}$ らの報告によるあので，污染ロットから選ん だ 20 粒中 12 粒から $\mathrm{AF}$ が検出され $\mathrm{AFB}_{1}$ の污染量は $0.174 \mu \mathrm{g} /$ 粒 $(300 \mathrm{ppb}) \sim 418 \mu \mathrm{g} /$ 粒 $(1100 \mathrm{ppm})$ と広範 囲に変動している。ロット 2 は, 著者らが6.77市販の落花 生加工品の行政検査で見つけたスーダン産小粒種のもの である. 同一ロットの原料豆から不良粒を選別し，その 330 粒中 75 粒から $\mathrm{AF}$ が検出され, $\mathrm{AFB}_{1}$ 污染量は $0.117 \mu \mathrm{g} /$ 粒 $(390 \mathrm{ppb}) \sim 341 \mu \mathrm{g} /$ 粒 $(1140 \mathrm{ppm})$ の範囲 にわたり, Cucullu の結果と一致している。 ロット 3 は 東京都衛生局の調査 ${ }^{8}$ によるもので, 100 粒の測定で 22 粒から $\mathrm{AF}$ が検出され, $\mathrm{AFB}_{1}$ 污染量は $0.008 \mu \mathrm{g} /$ 粒 (1 粒を $0.4 \mathrm{~g}$ として, $20 \mathrm{ppb}) \sim 97.0 \mu \mathrm{g} /$ 粒 $(243 \mathrm{ppm})$ と 前の 2 ロットよりは污染濃度は 1 桁低かったが, 測定值 の広がりはいずれあ 5 桁にわたった。なお，表 1 には粒 あたりの $\mathrm{AFB}_{1}$ 污染量 $(X)$ 分布を $X \leqq 0.5 \mu \mathrm{g}, 0.5 \mu \mathrm{g}<X$ $\leqq 10 \mu \mathrm{g}$ 及び $10 \mu \mathrm{g}<X$ の 3 区分に分けて示したが，こ れは後に述べる $\mathrm{AF}$ の定性分析評価のためのものであ る.

トゥモロコシにおけるマイコトキシンの粒污染： Shotwell ら9)によれば，カビ污染した（主としてA. flavus）トウモロコシ 140 粒のうち, 16 粒に $\mathrm{AFB}_{1}+\mathrm{B}_{2}$

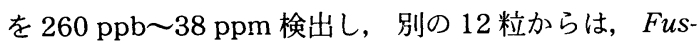
arium 菌カビ毒であるゼアラレノンを $9.00 \mathrm{ppm} \sim 1700$ $\mathrm{ppm}$ 検出した。 さらに, 別の調查では ${ }^{10}, 51$ 粒中 42 粒 に $\mathrm{AF}$ を検出し, それらの $\mathrm{AFB}_{1}+\mathrm{B}_{2}+\mathrm{G}_{1}+\mathrm{G}_{2}$ (以下,

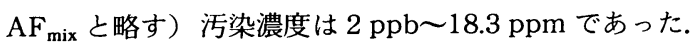
その他, Lee ら ${ }^{11)}$ も 198 粒中, 62 粒に $\mathrm{AFB}_{1}$ を 100 $\mathrm{ppb} \sim 80 \mathrm{ppm}$ の範囲で検出し, また, 上村 ${ }^{12}$ は, 輸入の
ポップコーンにFusarium 菌カビ毒であるデオキシニバ レノール (以下, DON と略す) を検出し, 污染ロットか ら分離した 100 粒中, 14 粒に DON を平均 $8.14 \mathrm{ppm}$, 範囲 $0.06 \mathrm{ppm} \sim 44.94 \mathrm{ppm}$ と 3 桁にわたって検出し た.

小麦におけるマイコトキシンの粒污染：上村は12), Fusarium 菌で污染した国産の小麦 100 粒の DON の污 染調查をした。本菌で污染した穂から分離した 59 粒か ら平均污染濃度 $4.8 \mathrm{ppm}$ を検出し, 範囲は $0.08 \mathrm{ppm}$ $33.3 \mathrm{ppm}$ であった。 このように，粒ごとの污染は 3 桁 の濃度範囲で変動しているが, 本事例のように污染粒率 が $59 \%$ と高いこと, 一定重量試料中の粒数が落花生や トウモロコシの 20〜30 倍になっていることなど, サン プルから見た污染の不均一性は, 同じ重量を比較すれば 落花生よりは低いものと思われる.

その他粒状農産物の AF 粒污染：Lee 及び Russel は ${ }^{13)}$ 綿実について調へ, 24 粒についての AF 污染濃度 は $0.231 \mathrm{ppm} \sim 151.3 \mathrm{ppm}$ の範囲であった.

以上のように, 粒状農産物の不均一なマイコトキシン 粒污染事例を示したが, 次にマイコトキシン污染濃度を 推定する際に, この不均一性がどのように影響するかを 述べる.

3. ロットのマイコトキシン污染濃度を推定する際の 誤差の要因

Whitaker ら ${ }^{14}$ は, 粒状の農産物のマイコトキシン検 査のための一般的な分析の過程を, 次の 3 段階に分け て, それぞれの過程から生ずる誤差の大きさを検討し た. 


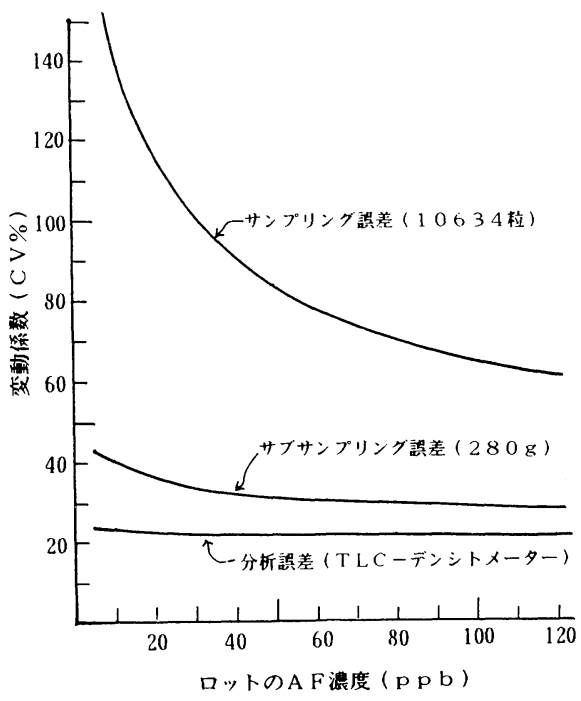

図 1. 㔀き身落花生のアフラトキシン分析に伴う誤 差の要因

一サンプルの平均值の測定に伴う変動係数の 比較一

（1）ロットからサンプルを分取する（サンプリング誤 差).

（2）サンプルを粉砕して微粒子となし，粉砕したサン プルからその一部を取って分析用のサブサンプルとする (サブサンプリング誤差).

(3) サブサンプルからマイコトキシンを抽出し, 分析 上の妨害物質を除去した後定量する (分析誤差).

彼らは, 以上の 3 段階に生ずる誤差を, 29 の $\mathrm{AF}$ 濃度 段階 (3〜111 ppb) の異なる市販の剝き落花生ロットを を用いて，サンプルサイズ 10,634 粒， サブサンプルサ イズ $280 \mathrm{~g}$ 及び各サブサンプル抽出物の繰り返し $\mathrm{AF}$ 定量などの条件を設定し, 延べ 3,336 回の分析を行っ た.これらの 3 つの要因のそれぞれについて，ロットの $\mathrm{AF}$ 平均濃度 $\bar{X}$ に対する分散值 $\left(\delta_{x}^{2}\right)$ を, 変動係数 $(\mathrm{CV}$ $\left.\%=\sqrt{\delta^{2}}{ }_{x} / \bar{X} \times 100\right)$ に変換して, それぞれの誤差の要因 を比較した. 図 1 に示したように, 污染濃度の小さいほ ぞ， 3 成分とも CV は大きくなる. 中でも, サンプリン グによる誤差は，ロットが低濃度であるほど極端に大き くなることが曲線から分かる. 例えば, $20 \mathrm{ppb}$ の $\mathrm{AF}$ 平 均濃度のロットの場合, サンプリングによる変動係数は $114 \%$ ，サブサンプリングでは $37 \%$ であったのに対し て, 分析上の誤差は全濃度を通じて約 $22 \%$ と一定であ った。このように，剝き身落花生の $\mathrm{AF}$ 污染の例をあげ て, ロットのマイコトキシン污染を推定する際に, サン プリング誤差が最も大きな要因となることを示した。 サ ンプルの測定值の変動は $\mathrm{AF}$ 污染のみならず, 他のマイ コトキシンについても同様であることは，第 2 節で述へ
た不均一な粒污染の実態から推察できる。したがって, 検查対象となる品目の粒が大きくて，一定量のサンプル 中の粒数が少ないほど，サンプル中の污染粒率が低下 し，サンプリング誤差を大きくすることが分かる.

4. サンプリングを評価するための確率統計学上の考 え方及び検督特性曲線

\section{1 負の二項分布}

これまでは，マイコトキシンの不均一な粒污染が，口 ットの污染濃度を推定する際の分析值に極めて大きな变 動を与えることを述べた。 そこで，この変動が全くデタ ラメに発生するむのではなく, ある一定の規則, 例えば 統計学上の確率分布則に関連付けられているのではない か, あしそうであれば, これらの変動を確率という物差 しで評価できる。この変動の確率論から見た研究は, 落 花生の大量生産国アメリカにおいて進められた。後に我

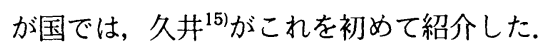

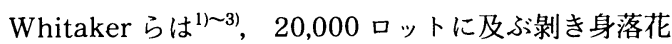
生の $\mathrm{AF}$ 污染デー夕を基に，あるロットの落花生の粒ご との $\mathrm{AF}$ 污染濃度 (量) $\chi_{\mathrm{a}}$ の出現する確立 $\mathrm{P}_{\mathrm{a}}$ が, 確率密 度関数の一つである負の二項分布法則に従うことを見出 した.さらに， $\chi_{\mathrm{a}}$ が $\chi_{\mathrm{a} 1}, \chi_{\mathrm{a} 2}, \chi_{\mathrm{a} 3}, \cdots \chi_{\mathrm{a} N}$ というように, それぞれが，お互いに独立して出現する時，それらの総 和 $\left(\chi_{\mathrm{a} 1}+\chi_{\mathrm{a} 2}+\chi_{\mathrm{a} 3}+\cdots+\chi_{\mathrm{aN}}\right)$ の出現する確率もまた負の 二項分布法則に従うとした (独立した事象の加成性).す なわち，このロットに対して $\left(\chi_{\mathrm{a} 1}+\chi_{\mathrm{a} 2}+\chi_{\mathrm{a} 3}+\cdots+\chi_{\mathrm{aN}}\right)$ は, $N$ 粒から構成されるサンプルの一つに他ならない.

そして, サンプル平均值 $\bar{\chi}_{\mathrm{a}}=\left(\chi_{\mathrm{a} 1}+\chi_{\mathrm{a} 2}+\chi_{\mathrm{a} 3}+\cdots+\chi_{\mathrm{aN}}\right) /$ $N$ は, $N \cdot \bar{\chi}_{\mathrm{a}}=\left(\chi_{\mathrm{a} 1}+\chi_{\mathrm{a} 2}+\chi_{\mathrm{a} 3}+\cdots+\chi_{\mathrm{aN}}\right)$ と変形できるか ら, $N \cdot \bar{\chi}_{\mathrm{a}}$ あまた負の二項分布に従う. 図 2 には複数の口 ット $\mathrm{L}_{a}, \mathrm{~L}_{b}, \mathrm{~L}_{c}, \cdots \mathrm{L}_{m}, \mathrm{~L}_{n}$ について, ロット及びサンプ ルの一般的な関係を示した。ここで，口ット中の粒の重 量がすべて同じであれば $\chi_{\mathrm{a}}$ は粒の污染濃度, $N \cdot \bar{\chi}_{\mathrm{a}}$ はサ ンプルの污染濃度として表すことができる.

負の二項分布関数 (確率密度関数) は次式で表される.

$$
f(r)=\frac{\Gamma(r+N k)}{r ! \cdot \Gamma(N k)} P^{N k} \cdot Q^{r}
$$

ただし，

$$
P=\frac{k}{M+k}, \quad Q=1-P
$$

とする.

ここで,

$\Gamma(\quad)=$ ガンマ関数

$M=$ ロットの真の平均濃度（量）

$k=$ ロットごとに見られる個々の粒の $\mathrm{AF}$ 濃度（量） に関する变動係数（Mによって左右される）, Whitaker らは, 実験的に $k=(2.0886+2.3898$ $M) \times 10^{-6}$ なる関係式を得た。

$N=$ サンプル中の粒数

$r=N \cdot \bar{\chi}$ (サンプル中の $\mathrm{AF}$ 濃度 (量)；サンプルごと 


\section{ロット ロットの真のAF 粒中のA F 濃度（量） N粒から成るサンプル中のA F 濃度（量）} 平均濃度 (量)

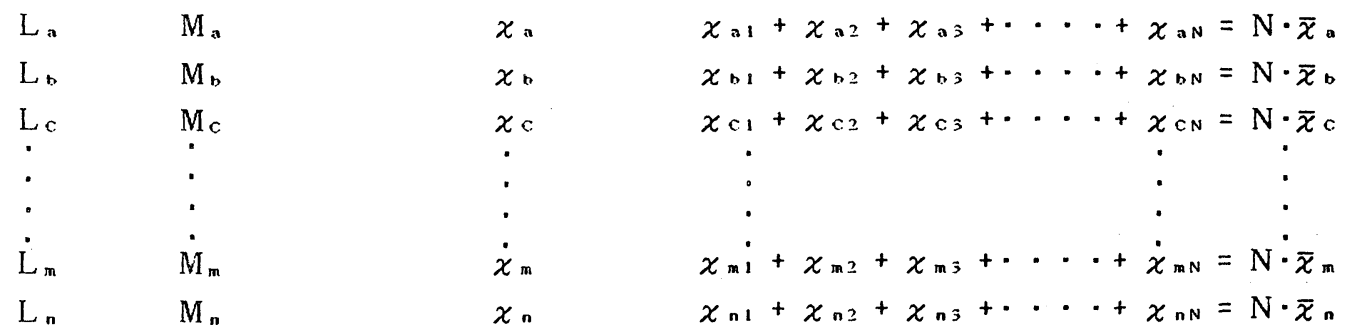

図2，負の二項分布に従う㔀き身落花生の粒及びサンプル中のアフラトキシン濃度（量), ロット並 びにロットの真の平均濃度の関係 $\bar{\chi}=$ サンプルの平均 $\mathrm{AF}$ 濃度（量）

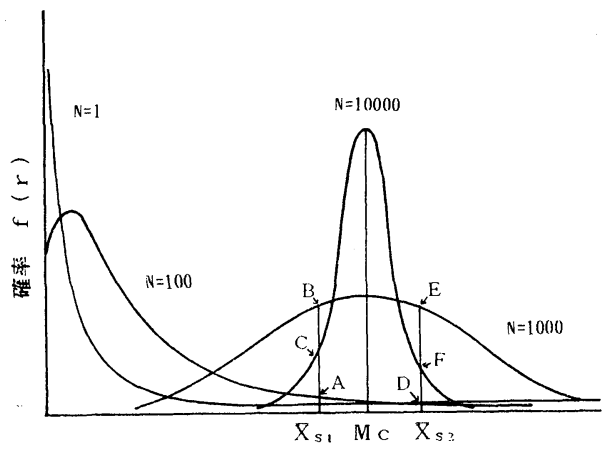

サンプルの测定值 ( p p b )

図 3. 㔀き身落花生のサンプルサイズの変化に伴う 負の二項分布による確率密度曲線への影響 $\bar{X}$ : 規制值 $M_{\mathrm{c}}$ : 平均污染濃度 $N$ : サンプルサイズ

に変動する）

$\tilde{\chi}=$ サンプルの全粒の平均濃度（量）

ここで，ガンマ関数など数学的な解説は, 著者の専門 でないので，㔀き身落花生の AF 分析に関連した説明を する.

\section{2 負の二項分布関数から見たサンプリングサイズ と AF 規制値}

前述の式 (1) について, 剝き身落花生のサンプルサイ ズ（粒数）を変化させた場合，サンプルの測定值の出現 率と $\mathrm{AF}$ 規制值との関係を述べる.

今, 真の平均污染濃度 $M_{\mathrm{c}}$ をもつロットから，異なっ たサンプルサイズ, $N=1,100,1,000$ 及び 10,000 粒を 各サンプルサイズについてそれぞれ繰り返し取り出し分 析すると, サンプルの測定值の出現率は図 3 に示したよ うなグラフが描かれる，1 粒ずつ取り出すと出現率は 0 付近に極めて多く集中し, 高い濃度の出現率は急速に減
少するが, 確率は 0 にはなかなか達しない， $N=100$ 粒 のサンプリングでは，0 付近に見かけ上のピークがある が，污染濃度が増すにつれて，広い範囲にわたって徐々 に出現率が隇少する。したがって，この程度のサンプル 量からは，全く偶然にしか $M_{\mathrm{c}}$ に近い測定值は得られな い. 100 粒といった少数のサンプルでは，サンプル中に 取り込まれる AF 污染粒の絶対数が減少し, 污染粒を全 く抜き取らない確率の増加と, 低濃度に污染した粒だけ を取り出す確率の増加により 0 付近の確率が高まる. 粒 数を 1,000 位に增すと, サンプルの测定值は $M_{\mathrm{c}}$ を中心 に分布するようになる。しかし，この程度の少数では, その変動幅は 4 桁にあ達する. 10,000 粒であ時には, 2 桁の変動幅の見られることがある. サンプルサイズの多 いほど, 変動幅は狭くなって, 正確なロットの污染濃度 の推定ができる.これらの実测例としては, Knütti 及び Sclatter らの剥き身落花生の AF 污染 ${ }^{16)}$, ならびに上村 の小麦の DON 污染に関する報告 ${ }^{12)}$ がある.

次に確率密度曲線と AF 規制值との関連について述べ る.

【ロットの真の $\mathrm{AF}$ 平均污染濃度が規制值 $\bar{X}_{\mathrm{s} 1}$ を越えて いる場合： $M_{\mathrm{c}}>\bar{X}_{\mathrm{s} 1}$ 】

本来，このロットは，すべて拒否されるべきものであ るが，例えば, $\cdot N=100,1,000$ 及び 10,000 で描かれる 確率密度関数と, 規制值 $\bar{X}_{\mathrm{si}}$ について横軸上に立てた垂 線との交点 $\mathrm{A}, \mathrm{B}$ 及び C よりも左側（AF 濃度の規制值 $\bar{X}_{\mathrm{s} 1}$ より低い側）に相当する曲線の部分は，これらのサ ンプルサイズで, サンプルの分析值が $\bar{X}_{\mathrm{s} 1}$ より低く出現 する確率を意味するから，そのロットが誤って受け入れ られる確率となる。すなわち，交点 $\mathrm{A}, \mathrm{B}$ 及び Cより左 側の確率密度曲線と横軸の間に挟まった面積が, 誤って 受け入れられる確率といえる.このことを消費者リスク と言う. 原則的には $N=100>N=1,000>N=10,000$ の順に消費者リスクが大きい.

【ロットの真の平均 $\mathrm{AF}$ 污染濃度 $M_{\mathrm{c}}$ が規制值 $\bar{X}_{\mathrm{s} 2}$ を越 


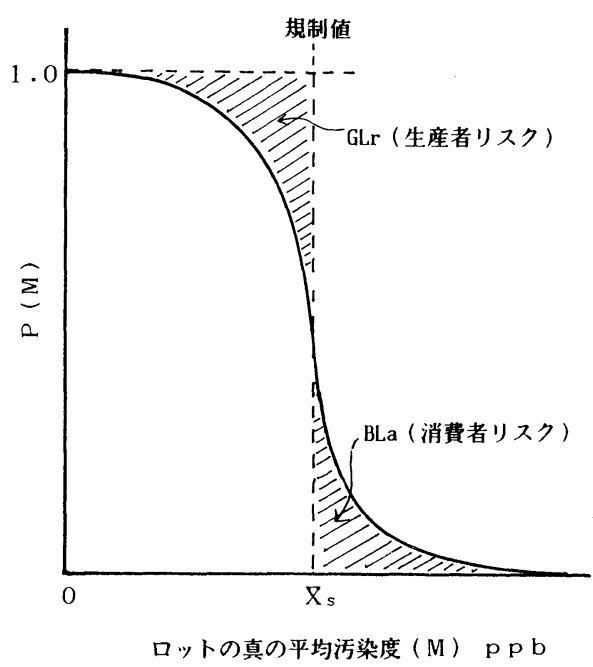

図4．検查特製曲線（OC-曲線）と消費者リスク及び 生産者リスク

\section{えていない場合： $M_{\mathrm{c}} \leqq \bar{X}_{\mathrm{s} 2}$ 】}

図 3 において, 規制値 $\bar{X}_{\mathrm{s} 2}$ から立てた垂線と $N=100$, 1,000 及び 10,000 のサンプルサイズの確率密度曲線と の交点を $\mathrm{D}, \mathrm{E}$ 及び $\mathrm{F}$ とすると，その交点より右側（AF の高濃度側）の曲線部分が，このサンプルサイズで測定 する時, 規制值 $\bar{X}_{\mathrm{s} 2}$ を越えたかのように出現する確率で あり， $\bar{X}_{\mathrm{s} 2}$ を越えたこれらの曲線部分と横軸との間に挟 まった面積の割合が誤って拒否される確率の総和に相当 する．このことを生産者リスクと言う．図 3 は説明のた めに単に曲線が重ならないように図案化してあるので, 図加得られる絶対值は真の数字とは違って描かれてい る.

\section{3 検查特性曲線}

今, $M$ なる $\mathrm{AF}$ 平均濃度をあつロットに対し, サンプ ルサイズ $N$ 及び $\mathrm{AF}$ 規制值 $\bar{X}_{\mathrm{s}}$ の条件で検查をすると, ロットを受け入れる確率の総和は, 確率密度関数 $f(r)$ を 0 から $\bar{X}_{\mathrm{s}}$ までの間について積分した累積確率に等しい。 この累積確率を $P(M)$ で示すと, $P(M)$ は $f(r)$ の確率分 布関数として式 (2) で表される.

$$
P(M)=\sum_{r=0}^{N X_{s}} f(r)
$$

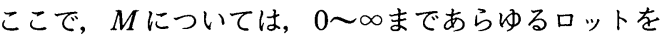
想定して, 段階的に $M=1,2,3,4, \cdots, \infty$ というように シミュレートし, 順次 $P(1), P(2), P(3), \ldots, P\left(M_{\infty}\right)$ をコン ピューターで計算する. 縦軸に $P(M)$ 值を横軸に $M$ 値 （ロットの真の平均污染濃度）をプロットすると図 4 の ようなシグモイド曲線が描かれる．この確率分布曲線の ことを検查特性曲線 (OC-曲線) と呼んでいる. そして, $N$ 及び $\bar{X}_{\mathrm{s}}$ は，検査の条件として定められるから，Mを 0〜のまでシミュレートすることによって， その試験法
に特有の OC-曲線が求められる.ここで $M=0$ であれ ば, そのロットは当然全部受け入れられるから， $P(M)=$ 1 （または 100\%）となる。ロットの $M$ が 0 から規制値 $\bar{X}_{\mathrm{s}}$ までの間, すなわち, あるロットの真の $\mathrm{AF}$ 平均濃度 $M_{\mathrm{c}}$ が $M_{\mathrm{c}} \leqq \bar{X}_{\mathrm{s}}$ ( $M$ は真の $\mathrm{AF}$ 平均濃度の一般的な総称 で， $M_{\mathrm{c}}$ はそのうちある特定の值を指す） の範囲であれ ば，すべて受け入れられるはずであるが，そのロットか ら分取したサンプルの測定値から合否を判定するので, ある確率で規制値 $\bar{X}_{\mathrm{s}}$ を越えたとして拒否されてしま う。この誤った判定，すなわち生産者が良い品物を悪い 之判定されて受ける経済的損失を, 生産者リスクと呼ん でいる (図 4 の左半分の斜線を引いた部分の確率に相当 する). 一方, $M_{\mathrm{c}}$ が規制值 $\bar{X}_{\mathrm{s}}$ を越えている場合，これら のロットはすべて拒否されるべきであるが，ある確率で 受け入れられ，消費者が食することによって肉体的な損 害を被る危険性がある。この誤って受け入れられる確率 を消費者リスクと呼んでいる (図 4 の右半分の斜線の部 分の確率に相当する). OC-曲線は，規制が厳しくなれば なるほど（ $\bar{X}_{\mathrm{s}}$ の值が小さくなる） 0 濃度の方向に移動 し，また，サンプルサイズが多くなるほど曲線がシグモ イド (て')から垂直なクランク型 (几)へ之変化する (誤っ た判定をされる確率, 両リスクに相当する面積が小さく なる).

\section{4 検査特性曲線を用いたサンプリング法評価のた めの統計指標}

存在する全ロット $L$ が, 定められた規制值 $\bar{X}_{\mathrm{s}}$ とサン プルサイズ $N$ の条件で検査を受けると, 受け入れられ る確率は式 (2) で求められる.

ここで, あらかじめ真の $\mathrm{AF}$ 平均濃度 $M$ を持つロッ 卜の比率を $f(M)$ とすると, $L$ のうち真の平均値 $M$ を持 つロット数は, $L \cdot f(M)$ となる. 実際に, $f(M)$ は, サン プルサイズ $N$ を数万粒というように大きくした場合に, 非常に多くのロットの実態調查の積み重ねによって近似 值的に得られる. $N$ 粒の検查で規制值 $\bar{X}_{\mathrm{s}}$ 以下として受 け入れられるロット数は, $L \cdot f(M) \cdot P(M)$ であるから， $M$ があらゆる濃度 0 〜を取り得ることから，Lのうち 受け入れられるロット数 $L_{a}$ は，式(3)で表される.

$$
L_{\mathrm{a}}=\sum_{M=0}^{\infty} L \cdot f(M) \cdot P(M)
$$

この $L_{\mathrm{a}}$ の中には，真の $\mathrm{AF}$ 平均濃度が規制值 $\bar{X}_{\mathrm{s}}$ を越 えたものも一部受け入れている.

$L_{\mathrm{a}}$ のうち, ロットの真の $\mathrm{AF}$ 平均濃度 $M_{\mathrm{c}}$ が規制值 $\bar{X}_{\mathrm{s}}$ を越えていない範囲 $\left(M_{\mathrm{c}} \leqq \bar{X}_{\mathrm{s}}\right)$, すなわち, 良いロット が良いとして受け入れられるロットの総数 $\left(G L_{\mathrm{a}}\right)$ は, 式 (4)で表される.

$$
G L_{\mathrm{a}}=\sum_{M=0}^{M_{\mathrm{c}}} L \cdot f(M) \cdot P(M)
$$

また，悪いロットが良いとして受け入れられる消費者 リスクに相当するロット数 $\left(B L_{\mathrm{a}}\right)$ は, 式 (5) で表される. 


$$
B L_{\mathrm{a}}=\sum_{M_{\mathrm{c}}+\Delta}^{\infty} L \cdot f(M) \cdot P(M)
$$

ここで $\Delta$ は, $M_{\mathrm{c}}$ をわずかに上回る $\mathrm{AF}$ 濃度で $M_{\mathrm{c}}+\Delta$ が規制値 $\bar{X}_{\mathrm{s}}$ を越えるとして検出可能な最小の值を意味 する（図 3 では $M_{\mathrm{c}}+\Delta$ は $\bar{X}_{\mathrm{s} 1}$ 及び $\bar{X}_{\mathrm{s} 2}$ のわずかに右側 にあることを意味する).

拒否される良いロット数 $\left(G L_{\mathrm{r}}\right)$, すなわち生産者リス クに相当するものは，式(6)で表される.

$$
G L_{\mathrm{r}}=\left[\sum_{M=0}^{M_{\mathrm{c}}} L \cdot f(M)\right]-G L_{\mathrm{a}}
$$

ここで

$$
\left[\sum_{M=0}^{M_{c}} L \cdot f(M)\right]
$$

は, 存在するすべての良いロット数を表す.

ある真の $\mathrm{AF}$ 平均濃度 $M$ を持つロットのうち, 検査 結果から受け入れられるロットの数にそれぞれのロット に対応する $M$ 濃度を乗ずると, 受け入れられるロット の $\mathrm{AF}$ 濃度が推定される[式 (7)].

$M \cdot L \cdot f(M) \cdot P(M)$

ここで, $M$ の取り得る値 0〜片ついて積分すると，受 け入れられるロット $L_{\mathrm{a}}$ の総 $\mathrm{AF}$ 量 $(\mathrm{AF} \times$ × ットの総合 したもの）が求められる。ここを受け入れられる全ロッ ト $L_{\mathrm{a}}$ で除すると，受け入れられる全ロットの $\mathrm{AF}$ 平均 濃度 $A$ が得られる〔式 (8)].

$$
A=\sum_{M=0}^{\infty} M \cdot L \cdot f(M) \cdot P(M) / L_{\mathrm{a}}
$$

この $A$ について，検查前と検査後を比較することに よって，その検查法の効果が明らかとなる.

\section{5. 各国の AF 検査のためのサンプリング法の評価}

\section{1 サンプリング法の評価に用いる AF 污染落花生 モデル}

1989 年に Whitaker らは, 30,000 ロットから構成さ れるアメリカの剥き身落花生の $\mathrm{AF}$ 分布モデルを J. of A.O.A.C. に報告した ${ }^{17)}$.それまで，それぞれの国で自国 の検査法の評価は行われていたが，ここでは，同じ AF 污染落花生モデルを用いて，一つのテーブルでの比較を 試みた. 本モデルは, USDA で実施された剝き身落花生 の $\mathrm{AF}$ 検查のためサンプルサイズ $21.6 \mathrm{~kg}$ を 3 回測定 という多量のサンプルから得られた測定デー夕を基にし ているので, 十分信頼性のあるモデルである.

\subsection{OC-曲線の作成}

USDA 法 (United States Department of Agriculture Plan): アメリカ合衆国における食品の AF の許容濃度 は， $\mathrm{AF}_{\text {mix }}$ として $20 \mathrm{ppb}$ 以下とされている，剝き身落 花生のサンプルサイズは，1 ロット当たり 45 トン以内 とし，4 袋につき 1 袋を対象とし，合計 $65 \mathrm{~kg}, 21.8 \mathrm{~kg}$ を 3 回サンプリングする. 分析はサンプル全粒粉砕法を 用い, 初めの第 1 サンプルを検査し， $\mathrm{AF}_{\text {mix }}$ として 12 ppb以下なら受け入れ， $60 \mathrm{ppb}$ を越えていたら拒否す
る。その間の場合は, 第 2 のサンプルを分析し, 第 1 と 2 のサンプルの平均值が $17 \mathrm{ppb}$ 以下なら受け入れ，30 $\mathrm{ppb}$ を越えていれば拒否する。そ間ならば第 3 のサン プルを分析し， 3 サンプルの平均值が $20 \mathrm{ppb}$ 以下なら 受入, 越えていれば拒否する。このように全ロットの $70 \%$ 以上を占める非污染品や低濃度污染品を 1 回の検 査で終了させ, 污染の疑いのあるロットについて第 2 及 び第 3 のサンプルで詳しく検査する，OC-曲線は報告の 中から引用した。

オランダ法: De Koe ${ }^{18)}$ の報告によれば, 一般食品の規 制值は $\mathrm{AFB}_{1}$ として $5 \mathrm{ppb}$ とされており; 特に輸入の落 花生に対しては $\mathrm{AFB}_{1} 3 \mathrm{ppb}$ 以下としている. サンプル サイズは, 1 ロット 25 トン以とし, 大粒種（1オンス 60 粒以下）は $10 \mathrm{~kg}$ を 4 回，小粒種（1オンス 60 粒を 越えるもの）は $5 \mathrm{~kg}$ を 4 回それぞれサンプルとする. 分析はサンプル全粒粉砕法を用い，4回の検査すべてが $\mathrm{AFB}_{1} 3 \mathrm{ppb}$ 以下の時受け入れる. 本法による OC-曲線 の作成は，Whitaker の報告に示された $P(M)$ 表を使用 した。 その際, アメリカの落花生 $\mathrm{AF}$ 分布モデルが $\mathrm{AF}_{\text {mix }}$ の濃度で表されているので, $\mathrm{AFB}_{1} 3 \mathrm{ppb}$ 以下の 規制值を， $\mathrm{AF}_{\text {mix }} 5 \mathrm{ppb}$ 以下としての規制値に変換した (De Koe の示した回帰式; $\mathrm{AF}_{\text {mix }}=\mathrm{AFB}_{1} \times 1.76$ から $\mathrm{AF}_{\text {mix }} 5.3$ と計算した)。 サンプルサイズは $N=12,500$ 粒（小粒種として $5 \mathrm{~kg}$ ）とし, Whitaker の報告から $P$ $(M)$ を算出し，4サンプルが同時に $\mathrm{AF}_{\text {mix }}<5 \mathrm{ppb}$ とな る同時生起確率 $[P(M)]^{4}$ を計算した。

TPI 法 (Tropical Products Institute Plan): Jewers ${ }^{19)}$ によれば，イギリスの剝き身落花生の $\mathrm{AF}$ 検查法は， 1 ロットを 20 トン以内とし， $3.5 \mathrm{~kg}$ を 3 回サンプリング する. 許容基準は $\mathrm{AF}_{\text {mix }} 30 \mathrm{ppb}$ 以下とされている. $P$ $(M)$ の算出は, サンプルサイズ $10.5 \mathrm{~kg}$ (小粒種 26,520 粒とし), Whitakerの $P(M)$ 表から計算した。

我が国の方法：麻袋入りロットの 90 袋から $1 \mathrm{~kg}$ をサ ンプリングし, $50 \mathrm{~g}$ を分析する. 検出限度 $\mathrm{AFB}_{1}$ として $10 \mathrm{ppb}$ の分析法で, 検出しなければ受け入れる.

$\mathrm{OC}$-曲線の作成は，厚生省 STAC 研究班の報告 ${ }^{201}$ の $P$ $(M)$ 表から計算した。サンプルサイズは, $1 \mathrm{~kg}$ 全粒粉砕 しその $50 \mathrm{~g}$ を分析する方法 (以下 $1 \mathrm{~kg}$ 粉砕分析法と呼 ぶ）に対しては $N=2,500$ (小粒種)，粒のまま $50 \mathrm{~g}$ を 1 回だけ分析する方法 (以下 $50 \mathrm{~g}$ 粒分析法と呼ぶ) は 125 粒とした. $\mathrm{AF}$ 規制值は, $\mathrm{AF}_{\text {mix }}$ として $16 \mathrm{ppb}$ 以下とし た（同研究班の報告, 回帰式 $\mathrm{AF}_{\text {mix }}=1.281 \times \mathrm{AFB}_{1}+$ 3.658 より, $\mathrm{AF}_{\text {mix }} 16.5$ を算出).

以上の四つの方法の検査特性曲線を図 5 に示した．単 に規制値のみから見かけ上の厳しさを見ると，オランダ 法 $\left(\mathrm{AFB}_{1} 3 \mathrm{ppb}\right)>$ 日本法 $\left(\mathrm{AFB}_{1} 10 \mathrm{ppb}\right)>\mathrm{USDA}$ 法

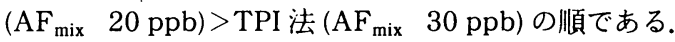
OC-曲線から見た厳しさはオランダ法>USDA 法>TPI 法>日本法の順之なる。特に我が国の方法は, 他の国の 


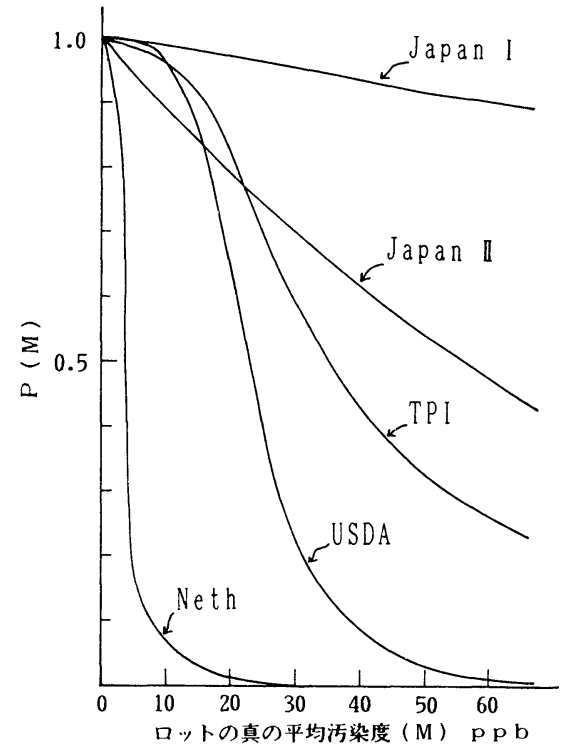

図 5. 各国の㔀き身落花生のアフラトキシン検査の ための検査特性曲線

方法に比べ極めてサンプルサイズが小さいので，污染口 ットを受け入れる確率が大きい，例えば，真の平均濃度 $60 \mathrm{ppb}$ のもので, $50 \mathrm{~g}$ 粒分析法では $91.2 \%$ を受け入 れ, $1 \mathrm{~kg}$ 粉砕分析法では, $49.3 \%$ 受け入れる. TPI 法 は $16.4 \%$ を, USDA 法は $0.2 \%$ を受け入れるが，オラ ンダ法は $30 \mathrm{ppb}$ のあのでも全く受け入れない.

\section{3 各国の AF 検査法に対する統計指標とその評価}

表 2 には，4.4で述べた統計指標を示した。 アメリカ の 30,000 ロットの検査前の平均 $\mathrm{AF}_{\text {mix }}$ 污染濃度は 6.55 ppb であった. USDA 法では, $93.5 \%\left(L_{\mathrm{a}}\right)$ を受け入れ, 消費者リスク $\left(B L_{\mathrm{a}}\right)$ は $1.8 \%$ ，生産者リスクは $1.4 \%$ と なった，両リスクはバランスが保たれている，受け入れ られる全ロットの平均 $\mathrm{AF}$ 濃度は $\mathrm{AF}_{\text {mix }}$ で $3.06 \mathrm{ppb}$ と なり, 検査前の $53.3 \%$ が隇毒される.

オランダ法は全ロットの $68.6 \%$ が受け入れられ，消 費者リスクは $1.3 \%$,生産者リスクは $7.7 \%$ と大きく消費 者保護に傾いている，受け入れられる全ロットの平均 $\mathrm{AF}_{\text {mix }}$ は $0.63 \mathrm{ppb}$ となり, $90.4 \%$ が減毒される.

イギリスの場合, $95.8 \%$ が受け入れられ，消費者リス クは $1.3 \%$,生産者リスクは $1.9 \%$ となり, 受け入れられ る全ロットの平均 $\mathrm{AF}_{\text {mix }}$ 濃度は $3.81 \mathrm{ppb}$ で, $41.8 \%$ が 減毒される.

我が国の場合， $50 \mathrm{~g}$ 粒分析法では（表 2；日本 I ） 99.1\%が受け入れられ，消費者リスクは $9.1 \%$ ，生産者 リスクは $0.4 \%$ と生産者保護に偏っている. 受け入れら れる全ロットの平均 $\mathrm{AF}_{\text {mix }}$ 濃度は $4.99 \mathrm{ppb}$ となり, $23.8 \%$ が減毒される， $1 \mathrm{~kg}$ 粉砕分析法は（日本 II ）, $94.9 \%$ が受け入れられ，消費者リスクは $6.7 \%$, 生産者
リスクは $2.1 \%$ となって，受け入れられる全ロットの平 均 $\mathrm{AF}_{\text {mix }}$ 濃度は $4.13 \mathrm{ppb}$ となり, $36.9 \%$ が減毒され る. なお, 我が国が落花生を輸入する場合, 輸入時の検 查では $50 \mathrm{~g}$ 粒分析法が行われ，そこで受け入れられた ものが消費地に回ってから，再び地方自治体などの検査 でチェックされている．その際, $200 \mathrm{~g} \sim 1 \mathrm{~kg}$ のサンプ ルサイズで分析されているので，最高 $1 \mathrm{~kg}$ で計算する 之， $94.2 \%$ が受け入れられ，消費者リスクは $6.4 \%$,生産 者リスクは $2.6 \%$, 受け入れられる全ロットの平均 $\mathrm{AF}_{\text {mix }}$ 濃度は $4.01 \mathrm{ppb}$ となって, $38.8 \%$ の減毒効果が 得られる。

\section{4 トゥモロコシ及び落花生の検查における AF 污 染ロットの分布と OC-曲線の比較}

表 3 には，Whitaker らの報告4).17)から，トゥモロコ シ及び剝き身落花生のアメリカにおける $\mathrm{AF}$ 污染分布モ デルの拔粋と, $\mathrm{AF}_{\text {mix }}$ 許容濃度 $20 \mathrm{ppb}$, サンプルサイズ $4.54 \mathrm{~kg}$ とした時の $P(M)$ 值を示した. トゥモロコシで は, 1,000ロットのうち許容濃度 $20 \mathrm{ppb}$ 越える739ロ ットが存在するが, 真の平均污染濃度 $18 \mathrm{ppbでは} 100 \%$ 受け入れられ, $30 \mathrm{ppbのあので} 21.9 \%$ が受け入れられ， $40 \mathrm{ppb}$ では全く拒否されることが示されている.一方, 落花生の分布モデルでは, 30,000ロット中 20 ppbのロッ トが180あり,そのうち $64 \%$ が受け入れられる.トゥモ

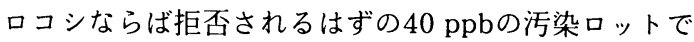
も落花生では $40 \mathrm{ppb} 27$ ロットのうち $40.6 \%$ が受け入 れられる.このように, トゥモロコシの方が, 落花生より あサンプリング誤差が少ないことから, 第2節で述べた ように, 粒污染濃度範囲は落花生と同様の変動幅が存在 するが, 污染粒率の低いロットの存在が少ないことがう かがわれ,トゥモロコシの方が, 落花生より検查結果の不 一致が少ないと言える.

\section{6. 二項分布法則によるマイコトキシンの定性分析に 必要なサンプルサイズの推定}

これまでは，多量から構成されるロット全体の污染濃 度の評価という観点からサンプルサイズを論じてきた。 そして, 我が国の㔀き身落花生などのサンプルサイズ 1 $\mathrm{kg}$ は，決してロット全体の污染濃度を推定するために 設定されたものでないことが示された。 それでは， $1 \mathrm{~kg}$ サンプルサイズが，どのような意味を持つか，定性試験 という立場から考えてみよう。

\section{1 我が国の剝き身落花生 AF 試験法の污染粒率か ら見た検出限度}

剝き身落花生は, 通常小粒の品種のもので約 $0.4 \mathrm{~g}$, 大 粒種で約 $0.85 \mathrm{~g}$ である. $1 \mathrm{~kg}$ 中には，それぞれ 2,500 粒及び 1,176 粒含まれる. 第 1 節で述べたように AF 污 染は 1 粒中の污染レベルが極めて高いものが含まれて おり， 1 粒で何 $\mathrm{kg}$ かのサンプルを規制值以上に污染し ているかのように見せてしまう.すなわち, 小粒種では, 2,500 粒に 1 粒 $(0.04 \%)$, 大粒種では 1,176 粒に 1 粒 


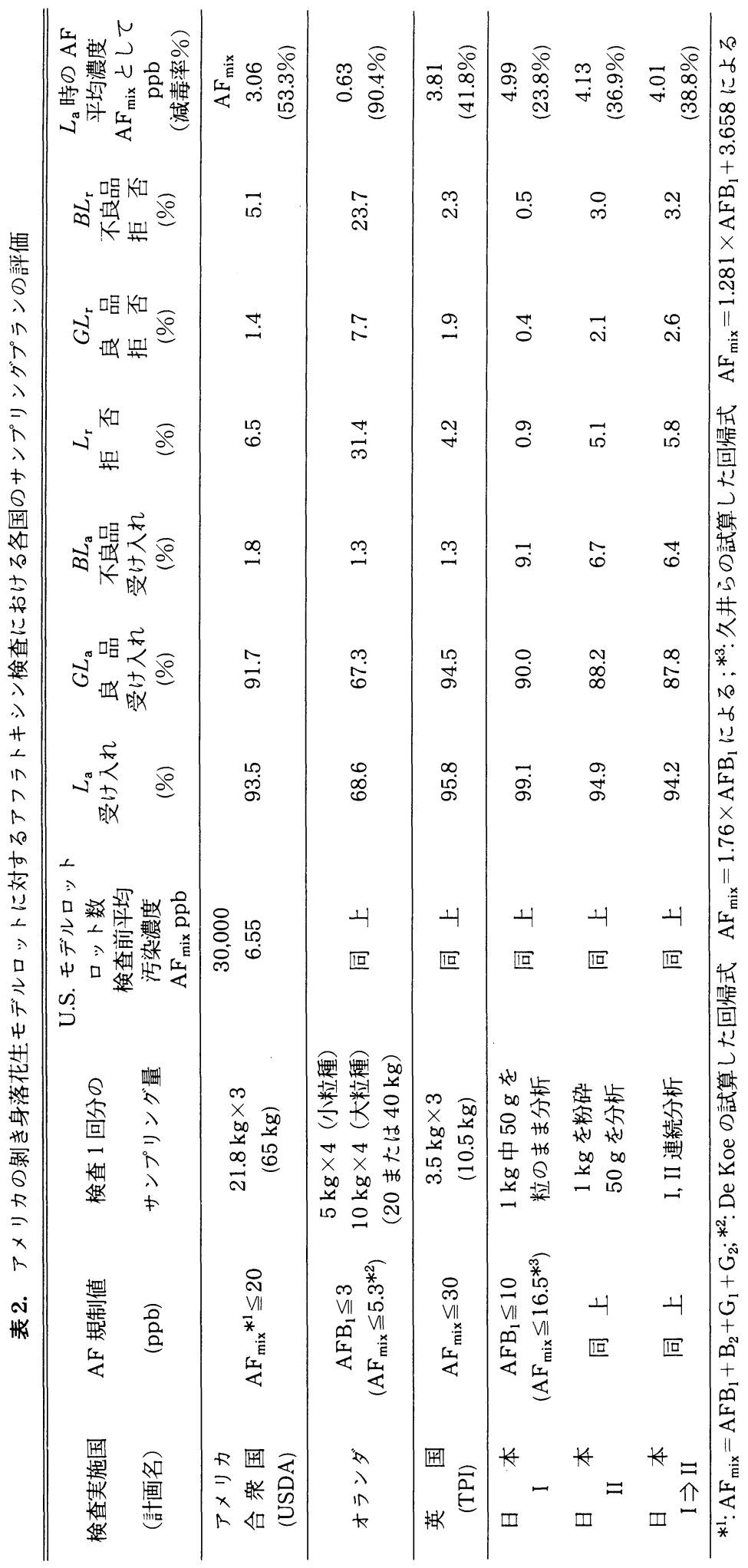


表 3. トゥモロコシ及び剝き身落花生のアフラトキシン検査特性曲線

\begin{tabular}{|c|c|c|c|c|c|c|}
\hline \multirow{2}{*}{$\begin{array}{c}\text { ロットの真の } \\
\text { 平均污染濃度 } M \\
\mathrm{AF}_{\text {mix }} \mathrm{ppb}\end{array}$} & \multicolumn{3}{|c|}{$\begin{array}{c}\text { トウモロコシ（U.S. モデルロット） } \\
\text { サンプルサイズ }(4.54 \mathrm{~kg})\end{array}$} & \multicolumn{3}{|c|}{$\begin{array}{c}\text { 㔀き身落花生（U.S. モデルロット） } \\
\text { サンプルサイズ }(4.54 \mathrm{~kg})\end{array}$} \\
\hline & 分布ロット数 & 分布率 $f(M) \%$ & $P(M)$ & 分布ロット数 & 分布率 $f(M) \%$ & $P(M)$ \\
\hline 0 & 350 & 35 & 1.000 & 15,000 & 50 & 1.000 \\
\hline 5 & 20 & 2.0 & 1.000 & 800 & 2.7 & 0.975 \\
\hline 10 & 16 & 1.6 & 1.000 & 430 & 1.4 & 0.860 \\
\hline 15 & 13 & 1.3 & 1.000 & 270 & 0.90 & 0.710 \\
\hline 18 & 12 & 1.2 & 1.000 & 210 & 0.70 & 0.668 \\
\hline 20 & 11 & 1.1 & 0.952 & 180 & 0.60 & 0.640 \\
\hline 25 & 8 & 0.8 & 0.563 & 90 & 0.30 & 0.536 \\
\hline 30 & 6 & 0.6 & 0.219 & 55 & 0.18 & 0.487 \\
\hline 35 & 5 & 0.5 & 0.120 & 36 & 0.12 & 0.411 \\
\hline 40 & 3 & 0.3 & 0.000 & 27 & 0.09 & 0.404 \\
\hline 50 & 2 & 0.2 & 0.000 & 17 & 0.06 & 0.340 \\
\hline
\end{tabular}

全 1,000 ロット

全 30,000 ロット

ただし，許容濃度を $\mathrm{AF}_{\text {mix }} 20 \mathrm{ppb}$ として計算した

表 4. 我が国における剝き身落花生のアフラトキシン検査における検出確率

\begin{tabular}{|c|c|c|c|c|c|c|}
\hline \multirow{2}{*}{$\begin{array}{c}\text { サンプル } \\
\text { サイズ }\end{array}$} & \multirow{2}{*}{ 污染粒率 } & \multicolumn{2}{|c|}{ 検出できる確率\% } & \multirow{2}{*}{ 污染粒率 } & \multicolumn{2}{|c|}{ 検出できる確率\% } \\
\hline & & 小粒（0.4 g/粒） & 大粒 $(0.85 \mathrm{~g} /$ 粒 $)$ & & 小粒 $(0.4 \mathrm{~g} /$ 粒 $)$ 大粒 & $(0.85 \mathrm{~g} /$ 粒 $)$ \\
\hline & A & & & $\mathrm{C}$ & & \\
\hline $50 \mathrm{~g}$ 粒の & 1 粒中 $\mathrm{AFB}_{1}$ & & & 1 粒中 $\mathrm{AFB}_{1}$ & & \\
\hline まま分析 & として 500 & & & として 500 & & \\
\hline & $\mathrm{ng}$ 以上污染 & & & $n g$ 以上污染 & & \\
\hline & されている粒 & & & されている粒 & & \\
\hline & の比率\% & & & の比率\% & & \\
\hline & 0.10 & 11.8 & 5.7 & 0.18 & 20.2 & 10.1 \\
\hline & 0.50 & 46.6 & 25.6 & 0.90 & 67.7 & 41.3 \\
\hline
\end{tabular}

\section{B}

$1 \mathrm{~kg}$ を粉 $\mathrm{A}$ の時, 1 粒

砕その 50 中 $\mathrm{AFB}_{1}$ と

$\mathrm{g}$ を分析 して $10 \mu \mathrm{g}$

以上污染され

ている粒の比

率\%
C の時, 1 粒 中 $\mathrm{AFB}_{1}$ と

して $10 \mu \mathrm{g}$

以上污染され ている粒の比 率\%

$\begin{array}{lll}0.10^{* 1} & 91.8(4.5)^{* 3} & 69.2(6.9) \\ 0.50^{* 1} & 100(1.5) & 99.7(2.4)\end{array}$

\footnotetext{
*1: 表 1 の污染粒率の実測值から, $\mathrm{A}$ 及び $\mathrm{C}$ は通常 $\mathrm{B}$ 及び $\mathrm{D}$ の 1.8 倍多く存在するから, $\mathrm{A}: \mathrm{B}=1.8: 1$, 及び C : $\mathrm{D}=1.8: 1$ によって補正した，例えば，本表 4 の A における污染粒率 $0.1 \%$ は，Bの $0.056 \%$ に相当する.

*2: それぞれ対応する污染粒率について, A に対する B の検出できる確率の倍率を示す. 例えば, $75.1 \%$ は $11.8 \%$ の 6.4 倍を意味する.

*3: *2 の場合と同様に, C に対する D の倍率を示す.
}

$(0.085 \%)$ 以上の高濃度污染粒が存在するかどうかが, 污染粒率から見た定性的検出限界となる.

また，粒のまま $50 \mathrm{~g}$ を分析してよしとする考え方も あり，この場合では，小粒種で 125 粒，大粒種で 59 粒 となって，それぞれ 125 粒に 1 粒 $(0.8 \%)$ 及び 59 粒に
1 粒 $(1.7 \%)$ が, 污染粒率から見た検出限界となる.した がって, これら両者のような少サンプルサイズでは, 検 出でき得るに足る AF に污染された粒のサンプル中での 混在率が重要となり, 污染粒率 $\left(C_{\mathrm{p}}\right)$ とサンプルサイズ $(N)$ の関係から，検出できる確率 $\left(P_{\mathrm{r}}\right)$ を論ずることがで 
きる.

本目的には二項分布法則が適当と考えられるので, $C_{\mathrm{p}}, N$ 及び $P_{\mathrm{r}}$ に一定の条件を与えて, それらの関係を推 計しで見よう。

ロット内の粒の重量がすべて同一と仮定し，污染粒率 $\left(C_{\mathrm{p}}\right)$ のロットから $N$ 粒をサンプリングし，その中に污染 粒を $\mathrm{k}$ 粒を取り出す確率は式 (9) で表される.

$$
P_{\mathrm{r}} \%=\frac{N !}{\mathrm{k} !(N-\mathrm{k}) !} \times C_{\mathrm{p}}{ }^{\mathrm{k}}\left(1-C_{\mathrm{p}}\right)^{(N-\mathrm{k})} \times 100
$$

ここで, サンプル中に 1 粒以上の污染粒が存在する 時, 必ず検出できるとすれば, $\mathrm{AF}$ が検出される確率は, $\mathrm{k}$ が $1,2,3, \cdots, N$ 粒まで取り出される確率の総和であ る.すなわち, 検出確率は式 (10)で表される.

$$
\sum_{\mathbf{k}=1}^{N} P_{\mathbf{r}} \%
$$

本確率式を使用して我が国の剝き身落花生の $\mathrm{AF}$ 検查 におけるサンプルサイズについて, サンプル中の污染粒 率を基準に, 検出確率 $\left(\mathrm{AFB}_{1}\right.$ として $10 \mathrm{ppb}$ 以上) を求 めた.

$50 \mathrm{~g}$ 粒分析法では, 指定された分析法の量的関係か ら換算して, $500 \mathrm{ng}$ を越えた $\mathrm{AFB}_{1}$ で污染した粒を 1 粒以上 $50 \mathrm{~g}$ のサンプル中に取り出した時, 検出するも のとした $\left(\mathrm{AFB}_{1}>10 \mathrm{ppb}\right)$.

$1 \mathrm{~kg}$ 粉砕分析法では, 同様の検出限度 $\left(\mathrm{AFB}_{1}>10\right.$ $\mathrm{ppb})$ を得るには，1粒当たり $10 \mu \mathrm{g}$ を越えた $\mathrm{AFB}_{1}$ で 污染されている必要がある.

同じ污染粒率という表現をしても，1 粒中の污染量が $500 \mathrm{ng}$ を越えるものなのか $10 \mu \mathrm{g}$ を越えるあのなのか を区別しなければならない，500 ng を越える粒といえ ば, 当然 $10 \mu \mathrm{g}$ を越える污染粒も含むので, 同じロット あるいはサンプル内の污染粒率を比較すれば, $500 \mathrm{ng}$ 超過粒の方が污染粒率は高くなる.

このことについて第 2 節の表 1 に戻って検討する. 同 一ロット内で $500 \mathrm{ng}$ を超過する粒の混在比と $10 \mu \mathrm{g}$ を 超過する粒の混在比を比較すると, 三つのロット事例か ら見ると平均 $1.8: 1[(\mathrm{~B}+\mathrm{C}): \mathrm{C}]$ となっている. したが って, $500 \mathrm{ng}$ 超過粒の污染粒率を $0.1 \%$ 及び $0.5 \%$ とす ると, 実際には, $10 \mu \mathrm{g}$ 超過粒の污染粒率は, $1 / 1.8$ を乗 じてそれぞれ $0.056 \%$ 及び $0.278 \%$ 程度になっている と推定される（表 4 の A 及びB).

この場合, $500 \mathrm{ng}$ を超過する粒の污染粒率が $0.1 \%$ (10 $\mu \mathrm{g}$ 超過粒では $0.056 \%)$ で, 小粒種では $50 \mathrm{~g}$ 粒分析 法で検出確率は $11.8 \%$ に対して， $1 \mathrm{~kg}$ 粉砕分析法で $75.1 \%$ となって, 後者の方が 6.4 倍検出確率が高くな る. 大粒種ではそれぞれ $5.7 \%$ 及び $48.2 \%$ となって, 1 $\mathrm{kg}$ 粉䂶分析法が 8.5 倍検出確率が高い.

同様の考え方で, $10 \mu \mathrm{g}$ を超過する粒の污染粒率を $0.1 \%$ 及び $0.5 \%$ とすると， $500 \mathrm{ng}$ 超過粒では， $0.18 \%$
表 5. 定性試験に必要な粒状農産物のサンプルサイズ*1

\begin{tabular}{ccc}
\hline \multicolumn{1}{c}{ 品 目 } & $\begin{array}{c}1 \text { 粒の重量 } \\
(\mathrm{g})\end{array}$ & $\begin{array}{c}\text { サンプルサイズ } \\
(\mathrm{g})\end{array}$ \\
\hline 【穀 類】 & & \\
トゥモロコシ & 0.32 & 800 \\
ポップコーン & 0.13 & 325 \\
ジャイアントコーン & 0.87 & 2,175 \\
小 麦 & 0.032 & 80 \\
大麦, 䔔麦 & 0.025 & 62.5 \\
米 & 0.023 & 57.5 \\
【種実類】 & & \\
アーモンド & 1.20 & 3,000 \\
ピスタチオ & & \\
殼 付 & 1.0 & 2,500 \\
可食部 & 0.55 & 1,375 \\
【豆 類】 & & \\
落花生 & & \\
小粒種 & 0.4 & 1,000 \\
大粒種 & 0.85 & 2,125 \\
小 豆 & 0.10 & 450 \\
\hline
\end{tabular}

*1: 全粒粉砕分析法を使用し, 各品目の污染粒率を $0.1 \%$ とした場合, $1 \mathrm{~kg}$ の小粒種落花生の検出確率 $91.8 \%$ に相当する検出確率を得るに必要なサンプル サイズを言う.

検出確率 91.8\%とは, 同一のロットから 1,000 回サ ンプリングを繰り返し分析したとき, 918 回は検出 するという結果を得る確率を言う。

及び $0.9 \%$ に相当する（表 4 の D と C).

$10 \mu \mathrm{g}$ を超過する粒の污染粒率を $0.1 \%$ とすると， 1 $\mathrm{kg}$ 粉砕分析法では，小粒種の検出確率は $91.8 \%, 50 \mathrm{~g}$ 粒分析法では $20.2 \%$ となり, 前者の方が 4.5 倍検出確 率が高い. 大粒種では, $1 \mathrm{~kg}$ 粉砕分析法が $69.2 \%, 50 \mathrm{~g}$ 粒分析法が $10.1 \%$ となって, 前者の方が 6.9 倍検出確 率が高い. 著者の調查では ${ }^{21)}, 1974$ 年〜1984 年の全国 の衛生研究所などの落花生とその加工品の $\mathrm{AF}$ 污染調査 で， 1,868 件中 46 件 (2.46\%) に，10 ppb を越える $\mathrm{AFB}_{1}$ を検出している.これらは，ほとんよ゙が $200 \mathrm{~g} 〜 1$ $\mathrm{kg}$ をサンプルサイズとし，全粒粉砕して分析している ので, $50 \mathrm{~g}$ 粒分析法による消費者リスクの部分を捕ら えているものと思われる.

6.2 豆類, 穀類及びナッツ類の污染粒率を $0.1 \%$ と した時の定性試験に必要なサンプルサイズ

$0.1 \%$ の污染粒率を持つ小粒落花生 $1 \mathrm{~kg}$ 粉砕法の検 出確率を $91.8 \%$ とし, それぞれの粒状農産物品目のサ ンプル中に 1 粒以上污染粒を取り出す検出確率を求め た（表 5).この場合, 各品目のマイコトキシンの粒污染 実態は, 落花生ほど詳しく明らかにされていないので, 污染濃度に関する条件付けは行わず, 污染粒を取り出す 確率のみに注目した。

本検出確率と同様の効果を期待するには，表 5 に示し 
たように, トウモロコシ $800 \mathrm{~g}$, 小麦 $80 \mathrm{~g}$, アーモンド $3,000 \mathrm{~g}$, ピスタチオ (殸付) $2,500 \mathrm{~g}$ などが必要である. 一粒の重量が小さい粒ほど，サンプルサイズは少なくて 済むようであるが，米や麦のような小さな粒の品目で は，繰り返し分析のことも考慮して 200〜300 g は必要 である。

\section{7. おわりに}

農産物のマコトキシン污染濃度を, 多量から構成され るロットについて推定する上で，いかにしてロットの性 質を正確に代表するサンプルを入手すべきかということ が品質管理の面では重要な課題の一つである，単に多く のサンプルサイズを取れば良いかと言うと，技術的及び 経済的な制約が存在する。この 20 年間, 主にアメリカ で取り組まれた成果は，小粒落花生のサンプルサイズと して 1 サンプル当たりおよそ 50,000 粒を 3 回取り，段 階的に検查する方法に収束しつつある，本方法は，口ッ ト全体を評価するに適しており，消費者に対しても，あ るいは生産者に対しても公正に対処できるとして定着し ている. 一方，貿易上の問題として，世界的に統一した 規制を求められる中，非常に厳しい規制を設けている才 ランダに対しては, J. of A.O.A.C. ${ }^{17)}$ に抗議の意味合いを 含めた報告が掲載されている。この点我が国の方法は貿 易摩擦を起こすことは有り得ない。

現在，世界の趨勢では，㔀き身落花生の $\mathrm{AF}$ 検査のた めのサンプルサイズは，ロット 1 トンについて $0.5 \mathrm{~kg}$ が一般的に認められている22). この比率から我が国のサ ンプルサイズを求めれば, $1 \mathrm{~kg}$ が代表できるロットは 2 トンと算出される．この比率は以前著者が，污染の予測 されるものほど母集団を小さくする必要があると主張し

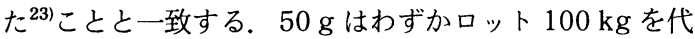
表するにすぎない.

さて，我が国は，食糧や飼料の多くを外国からの輸入 に頼らねばならない，多量のロットを港に保管して時間 をかけて詳しく検査するのは現実的ではなく，污染があ るかどうかを迅速に検査することが望まれる，したがっ て，㔀き身落花生 $1 \mathrm{~kg}$ のサンプルサイズは適当と思わ れるが，このサンプルサイズは，約 $0.1 \%$ 程度の污染粒 率を検出限度とする定性分析の意味を持つとも考えられ る. $0.1 \%$ の污染粒率では，小粒種で $91.8 \%$ の検出確率 が得られる。すでに，トウモロコシ及びピスタチオにつ いては $1 \mathrm{~kg}$ 粉砕分析法が厚生省から指示されている. したがって, $1 \mathrm{~kg}$ 全粒粉砕しその一部を分析し, 分析值 がサンプル $1 \mathrm{~kg}$ を代表するように改めることがより信 頼性を高めるものと考える.
謝辞

本稿をまとめるに当たり，資料の入手にご助力いただ きました国立衛生試験所衛生微生物部第三室長 一戸正 勝博士に深謝致します。

文献

1) Whitaker,T. B., Wiser, E. H.: J. Amer. Oil Chem. Soc. 46, 377 379 (1969).

2) Whitaker, T.B., Dickens, J. W., Wiser, E. H.: ibid. 47, 501 504 (1970)

3) Whitaker, T. B., Dickens, J. W., Monroe, R. J., Wiser, E. H.: ibid. 49, 590 593 (1972).

4) Whitaker, T.B., Dickens, J. W.: J. Assoc. Off. Anal. Chem. 66, 1055 1058 (1983).

5) Cucullu, A. F., Lee, L. S., Mayne, R. Y., Goldblatt, L. A.: J. Amer. Oil Chem. Soc. 43, 89 92 (1966).

6) 山本勝彦, 坪内春夫, 久田和夫, 坂部美雄：食衛誌。 24 , 396 402 (1983).

7) 山本勝彦：環境管理技術 3, 576～584 (1985).

8）東京都衛生局：各種食品に打ける力ビ及び力ビ毒污染防 止対策に関する調查研究実施結果, 149 153 (1989).

9) Shotwell, O. L., Goulden, M. L., Bothast, R. J., Hesseltine, C. W.: Cereal Chem. 52, 687 697 (1975).

10) Shotwell, O. L., Goulden, M. L., Hesseltine, J. W., Dickens, J. W., Kwolek, W. F.: ibid. 57, 206 208 (1980).

11) Lee, L. S. Lillehoj, E. B., Kwolek, W. F.: ibid. 340 343 (1980).

12）上村 尚：Fusarium 菌の産生するマイコトキシンに関 する研究 (学位論文) 50 55 (1986).

13) Lee, L. S., Russel, T. E.: J. Amer. Oil Chem. Soc. 58, 27 29 (1981).

14) Whitaker, T. B., Dickens, J. W.: J. Amer. Oil Chem. Soc. 51, 214 218 (1974).

15）久井伸治：公害と対策 15, 417～423 (1979).

16) Knütti, R., Schlatter, C.: Z. Lebensm. Unters. Forsch. 174, 122 128 (1982).

17) Whitaker, T. B., Dickens, J. W.: J. Assoc. Off. Anal. Chem. 72, 644 648 (1989).

18) De Koe, W.: J. Assoc. Off. Anal. Chem. 73, 809 813 (1990)

19) Jewers, K.: Res. Soc. Health J. 102, 114 118 (1982).

20）厚生省 STAC 研究班：食品の衛生検査における統計的手 法の改善に関する研究, 輸入落花生の AF 検查のための サンプリングに関する研究 (1978).

21) 山本勝彦：フードケミカル， 5, 78〜87 (1988).

22) Mycotoxins, Economic and Health Risks: Reporting No. 116, Nov., 58 (1989), Council for Agricultural Science and Technology.

23) 山本勝彦：マイコトキシン, No. 26, 7〜12 (1987). 